\title{
TARBP2 wt Allele
}

National Cancer Institute

\section{Source}

National Cancer Institute. TARBP2 wt Allele. NCI Thesaurus. Code C84408.

Human TARBP2 wild-type allele is located within 12q12-q13 and is approximately $6 \mathrm{~kb}$ in length. This allele, which encodes RISC-loading complex subunit TARBP2 protein, is involved in the modulation of RNA-mediated gene silencing and HIV gene expression. Mutation of the gene may be associated with endometrial, gastric, and colorectal cancers. Loss of the gene may be associated with defective processing of miRNA. 